\title{
Hardness of the High Pressure Die Castings from Alloy AlSi9Cu3 in dependence on the Sub- sequent Processing Technology
}

Iva Novakova, Jan Štverák, Jaromir Moravec

Technical University of Liberec. Studentská 2, 46117 Liberec 1. Czech Republic. E-mail: iva.novakova@tul.cz, jan.stverak@ksmcastings.com, jaromir.moravec@tul.cz

The paper deals with the hardness of pressure die castings in dependence on the method of their subsequent processing. As a crucial influence there was taken cooling rate of parts after their removal from the pressure die mould. Moreover there was monitored influence of the machining allowance and the thermal treatment. Measurement of hardness was done on die castings from alloy $\mathrm{AlSi9Cu3(Fe)} \mathrm{by} \mathrm{methods} \mathrm{acc.} \mathrm{to} \mathrm{Brinell} \mathrm{and} \mathrm{acc.} \mathrm{to} \mathrm{Rockwell.}$ Regarding reality that properties of die castings are influenced also by filling method, for the experiment there was chosen part casted by so-called central ingate where exists presumption for the uniform filling and thus also uniform distribution of casting properties. The measurement took place for 2 months after casting, machining and eventually after thermal treatment of parts. On the basic of measured hardness values by methods acc. to Brinell and Rockwell there was determined the converting coefficient between these values.

Keywords: High Pressure Die Casting, Hardness, AlSi9Cu3(Fe)

\section{Acknowledgement}

This paper was prepared thanks to financial support from the Student Grant Contest project 21005 (SGS 2015), from the TUL part within the framework of specific university research support.

\section{References}

[1] ROUČKA, J. (2004). Metalurgie neželezných slitin, pp. 42-55, Akademické nakladatelství CERM, Brno.

[2] MICHNA, Š., LUKÁČ, I. a kol. (2005). Encyklopedie hliníku, pp. 253 - 310, Adin s.r.o., Prešov SR.

[3] RAGAN, E. a kol. (2007). Liatie kovov pod tlakom, pp. 145 - 168, Adin s.r.o., Prešov SR.

[4] HONZÁTKO, R., MICHNA, Š, CAIS, J. (2013). The Influence of Porosity on Mechanical Properties of Casts Produced from Al - Si Alloys. In Manufacturing Technology, Vol. 13, September 2013, pp. 319 - 324.

[5] MICHNA, Š., NÁPRSTKOVÁ, N. (2012). Research into the causes cracking of aluminum alloys of $\mathrm{Al}-\mathrm{Cu}$ during mechanical machining. In Manufacturing Technology, Vol. 12, June 2012, pp. 47 - 51.

[6] NÁPRSTKOVÁ, N., CAIS, J., SVOBOdOVÁ, J. (2013). The Effect of Modification by Strontium of the AlSi7Mg0.3 Alloy on the Surface Roughness. In Manufacturing Technology, Vol. 13, September 2013, pp. 380384.

[7] KOPECKÝ, J. Závislost tvrdosti odlitků Al slitin na době stárnutí a průběhu tepelného zpracování. [online]. Praha: ČVUT, FS Praha. Dostupné z: http://stc.fs.cvut.cz/pdf13/2616.pdf.

[8] ŠERÁK, J. a kol. (2015) Vliv tepelného zpracování na mechanické vlastnosti a korozní odolnost hliníkových slitin. In Slévárenství, LXIII, Vol. 5 - 6, 2015, pp. 158 - 162.

[9] HURTALOVÁ, L., TILlOVÁ, E., CHALUPOVÁ, M. (2014). Prínos metalografie při studiu zlievarenských Al zliatin skupiny 4xxxx. In Slévárenství, LXII, Vol. 11-12, 2014, pp. 417 - 421.

[10] MARTINOVSKÝ, M., MÁDL, J. (2014). Vliv modifikátorů na obrobitelnost a vlastnosti Al-Si slitin. In Strojirenská technologie, XIX, Vol. 3 - 4, 2014, pp. 212 - 219.

[11] ČSN EN ISO 6506-1. Kovové materiály - Zkoušky tvrdosti podle Brinella - Část 1: Zkušební metoda. Praha: Český normalizační institut, 2006. 20 p. Tř́́dicí znak: 420359.

[12] ČSN EN ISO 6508-1. Kovové materiály - Zkoušky tvrdosti podle Rockwella - Část 1: Zkušební metoda. Praha: Český normalizační institut, 2006. 24 p. Tř́́dicí znak: 420360. 